\title{
PEMBUATAN DAN KARAKTERISASI MEMBRAN KOMPOSIT KITOSAN- SODIUM ALGINAT TERFOSFORILASI SEBAGAI PROTON EXCHANGE MEMBRANE FUEL CELL (PEMFC)
}

\author{
Siti Wafiroh $^{1 *}$, Suyanto Suyanto ${ }^{1}$, Yuliana Yuliana ${ }^{1}$ \\ Departemen Kimia, Fakultas Sains dan Teknologi, \\ Universitas Airlangga, Surabaya \\ *email: sitiwafiroh@yahoo.com
}

\begin{abstract}
Abstrak
Di era globalisasi ini, kebutuhan bahan bakar fosil semakin meningkat dan ketersediannya semakin menipis. Oleh karena itu, dibutuhkan bahan bakar alternatif seperti Proton Exchange Membrane Fuel Cell (PEMFC). Tujuan dari penelitian ini adalah membuat dan mengkarakterisasi membran komposit kitosan-sodium alginat dari rumput laut coklat (Sargassum sp.) terfosforilasi sebagai Proton Exchange Membrane Fuel Cell (PEMFC). PEM dibuat dengan 4 variasi perbandingan konsentrasi antara kitosan dengan sodium alginat 8:0, 8:1, 8:2, dan 8:4 (b/b). Membran komposit kitosan-sodium alginat difosforilasi dengan STPP 2N. Karakterisasi PEM meliputi: uji tarik, swelling air, kapasitas penukar ion, FTIR, SEM, permeabilitas metanol, dan konduktivitas proton. Berdasarkan hasil analisis tersebut, membran yang optimal adalah perbandingan $8: 1(\mathrm{~b} / \mathrm{b})$ dengan nilai modulus young sebesar $0,0901 \mathrm{kN} / \mathrm{cm}^{2}$, swelling air sebesar 19,14\%, permeabilitas metanol sebesar 72,7 $\mathrm{x}$ $10^{-7}$, dan konduktivitas proton sebesar 4,7 x $10^{-5} \mathrm{~S} / \mathrm{cm}$. Membran komposit kitosan-sodium alginat terfosforilasi memiliki kemampuan yang cukup baik untuk bisa diaplikasikan sebagai membran polimer elektrolit dalam PEMFC.
\end{abstract}

Kata kunci: kitosan, sodium alginat, terfosforilasi, PEMFC

\begin{abstract}
In this globalization era, the needs of fossil fuel certainly increases, but its providence decreases. Therefore, we need alternative fuels such as Proton Exchange Membrane Fuel Cell (PEMFC). The purpose of this study is preparation-and characterization of phosphorylated chitosan-sodium alginate composite membrane from brown seaweed (Sargassum sp.) as Proton Exchange Membrane Fuel Cell (PEMFC). PEM is produced with 4 variations of concentration ratio between chitosan and sodium alginate 8:0, 8:1, 8:2, and $8: 4(\mathrm{w} / \mathrm{w})$. Chitosan-sodium alginate composite membrane phosphorylated with 2 N STPP. The characterization of PEM include: tensile test, water swelling, ion exchange capacity, FTIR, SEM, methanol permeability, and proton conductivity. Based on the analysis result, the optimal membrane is ratio of 8:1 (w/w) with the value of Young's modulus about 0.0901 $\mathrm{kN} / \mathrm{cm}^{2}$, water swelling at $19.14 \%$, methanol permeability about $72.7 \times 10^{-7}$, and proton conductivity about $4.7 \times 10^{-5} \mathrm{~S} / \mathrm{cm}$. The phosphorylated chitosan-sodium alginate composite membrane has good potentials for the application of the polymer electrolyte membrane in PEMFC.
\end{abstract}

Keywords: chitosan, sodium alginate, phosphorylated, PEMFC 


\section{Pendahuluan}

Di era modern sekarang ini, aktivitas manusia semakin meningkat. Tingginya mobilitas manusia membuat kebutuhan bahan bakar semakin tinggi. Terutama kebutuhan bahan bakar fosil untuk kehidupan sehari-hari dan industri. Akan tetapi, bahan bakar fosil seperti BBM mulai langka. Untuk mengatasi permasalahan tersebut maka perlu adanya bahan bakar alternatif yang ramah lingkungan, murah dan aman. Sel bahan bakar atau fuel cell merupakan salah satu bahan bakar alternatif (Williams., 2011).

Fuel cell merupakan sel bahan bakar yang dapat menghasilkan arus listrik langsung melalui proses elektrokimia dengan mereaksikan gas hidrogen $\left(\mathrm{H}_{2}\right)$ dan oksigen $\left(\mathrm{O}_{2}\right)$ (Williams, 2011). Fuel cell direkomendasikan sebagai konversi energi alternatif untuk bahan bakar alat transportasi dan sumber energi. Dalam beberapa dekade ini perkembangan dunia semakin meningkat dan penggunaan fuel cell juga semakin marak karena bersifat efisien dan aman (Kim et al., 2011).

Fuel cell dapat dikelompokkan berdasarkan karakteristik elektrolit dan suhu operasinya, yaitu Phosphoric Acid Fuel Cell (PAFC), Solid Oxide Fuel Cell (SOFC), Molten Carbonate Fuel Cell (MCFC), dan Proton Exchange Membrane Fuel Cell (PEMFC) (Raharjo et al., 2007). Jenis fuel cell yang paling efektif digunakan adalah PEMFC karena operasionalnya yang mudah yaitu menggunakan membran elektrolit sehingga terhindar dari proses korosi, efisensi pada konversi tinggi mencapai $50 \%$, bebas polusi, pengoperasiannya relatif cepat, dan dapat dioperasikan pada temperatur rendah (Peng et al., 2014).

PEMFC yang biasanya digunakan adalah Nafion. Jenis membran ini terbuat dari bahan polimer sintetik yaitu Tetrafluoroetilen tersulfonasi (Thomas, 2008). Nafion memiliki konduktivitas proton yang tinggi yaitu $4,7 \times 10^{-2} \mathrm{~S} / \mathrm{cm}$ di bawah $100^{\circ} \mathrm{C}$, stabilitas termal tinggi $\left(280^{\circ} \mathrm{C}\right)$, dan prosentase penyerapan air yang rendah sebesar $15,2 \%$. Akan tetapi terdapat kelemahan pada tingginya permeabilitas metanol yaitu sebesar 27,6 $\mathrm{x}$ $10^{-8} \mathrm{~cm}^{2} / \mathrm{s}$ (Smitha et al, 2005). Meskipun nafion merupakan membran yang dominan digunakan pada PEM untuk bahan bakar hidrogen, permeabilitas metanol yang tinggi dapat mengganggu efisiensi fuel cell. Selain itu harga nafion sangat mahal dan harus impor dari luar negeri. Salah satu solusi untuk mengatasi masalah tersebut adalah mengganti membran nafion dengan membran lain yang harganya terjangkau serta hampir sama kinerjanya dengan nafion (Smitha et al., 2005). Oleh sebab itu muncul penelitian alternatif pengganti membran nafion. Salah satu alternatif tersebut adalah membuat membran dari polimer alam seperti sodium alginat dan kitosan.

Alginat merupakan suatu polisakarida hasil ekstraksi rumput laut coklat Sargassum sp. dan Turbinaria sp. yang banyak ditemukan di perairan Indonesia. Sodium alginat digunakan sebagai bahan dasar pembuat membran pada fuel cell. Sodium alginat larut dalam air dan memiliki kekuatan mekanik yang tinggi yaitu kekuatan tariknya sebesar 21,18 Mpa, memiliki ketebalan $140 \mu \mathrm{m}$ dan swelling metanol sebesar $0,31 \%$.

Selain sodium alginat, kitosan merupakan polimer alam yang sering digunakan sebagai membran penukar proton pada fuel cell. Kitosan berasal dari kitin yang mengalami deasetilasi. Kitosan hasil deasetilasi kitin memiliki daya serap yang tinggi terhadap air. Penambahan alginat dapat memperbaiki struktur ikat silang kitosan dalam membran sehingga menjadi lebih kaku dan membran menjadi lebih kuat dan stabil (Smitha et al., 2005). Komposit kitosan-sodium alginat menghasilkan kompleks poli-ion melalui ikat silang ionik yang akan meningkatkan sifat-sifat tertentu seperti kekuatan struktural dan stabilitas termal membran, serta memiliki nilai konduktivitas proton sebesar $0,042 \mathrm{~S} / \mathrm{cm}$ pada $30-32^{\circ} \mathrm{C}$ walaupun kecenderungan swelling 
berkurang (Smitha et al, 2005). Akan tetapi kitosan memiliki kelemahan yaitu konduktivitas protonnya $8,3 \times 10^{-5} \mathrm{~S} / \mathrm{cm}$ (Wan et al., 2003), swelling air tinggi hingga $55,2 \%$ serta stabilitas termal yang buruk. Kelemahan tersebut dapat diatasi dengan cara dikontrol melalui modifikasi kitosan menggunakan bahan pengikat silang (Xiang et al., 2009). pada penelitian Wan et al. (2003) dengan kondisi optimal dapat menurunkan swelling air hingga 49\%, dan meningkatkan konduktivitas proton hingga $1,2 \times 10^{-3} \mathrm{~S} / \mathrm{cm}$, selain itu senyawa yang digunakan tidak bersifat toksik (Wan et al., 2003) serta dengan crosslink sodium tripolifosfat (STPP) stabilitas termal meningkat hingga $271^{\circ} \mathrm{C}$ (Moura et al., 2008). Fosforilasi ini menggunakan sodium tripolifosfat. STPP merupakan polianion yang tidak beracun dan mudah membentuk gel. Kitosan merupakan polimer kationik yang dapat bereaksi dengan anion multivalen sodium tripolifosfat (STPP). Secara spontan kitosan akan membentuk gel dengan sodium tripolifosfat (STPP) (Moura et al., 2008). Oleh karena itu dalam penelitian ini dilakukan pembuatan membran fuel cell dari komposit kitosansodium alginat yang berperan sebagai membran penukar proton yang memiliki kinerja setara dengan Nafion.

\section{Metode Penelitian}

Alat dan Bahan

Alat yang digunakan dalam penelitian ini adalah cawan petri, hotplate, pengaduk magnetik, oven, furnace, timbangan analitik, buret, krus porselin, mortar, ayakan, loyang, kertas saring, indikator universal, viskometer Oswald dan seperangkat alat gelas yang ada di laboratorium Kimia Fisik Universitas Airlangga. Beberapa instrumen yang digunakan untuk penelitian ini adalah alat uji tarik AG-1S $50 \mathrm{KN}$ Autograph, SEM JEOL JSM-8360LA, FTIR Shymidzu tipe 8400 s, LCR meter untuk menentukan konduktivitas proton, dead end untuk mengukur permeabilitas metanol
Bahan yang digunakan dalam penelitian ini adalah rumput laut coklat (Sargassum sp.), kitosan (dari IPB dengan berat molekul 150.000-350.000 g/mol dan DD $78 \%$, akuades, kalium hidroksida $(\mathrm{KOH}$; Merck; 85\%), asam klorida ( $\mathrm{HCl}$; Merck; 37\%), Sodium Tripolifosfat (STPP; Merck; 93\%), natrium hidroksida $(\mathrm{NaOH}$; Merck; $99 \%)$, asam asetat glasial $\left(\mathrm{CH}_{3} \mathrm{COOH}\right.$; Merck; $100 \%)$, natrium karbonat $\left(\mathrm{Na}_{2} \mathrm{CO}_{3}\right.$; Merck; 99,9\%), natrium hipoklorit $(\mathrm{NaOCl}$; Sigma-Aldrich; 8\%), isopropil alkohol $\left(\mathrm{C}_{3} \mathrm{H}_{7} \mathrm{OH}\right.$; Merck; 99,5\%), dan metanol $\left(\mathrm{CH}_{3} \mathrm{OH}\right.$; Sigma-Aldrich ; 99,8\%).

\section{Prosedur Penelitian}

Ekstraksi sodium alginat dari Sargassum sp.

Sodium alginat dari rumput laut coklat (Sargassum $s p$ ) diekstraksi dengan menggunakan metode ekstraksi yang dikembangkan oleh Balai Besar Pengolahan Produk dan Bioteknologi Kelautan dan Perikanan Jakarta. Metode ekstraksi tersebut adalah metode ekstraksi jalur asam alginat. Sebelum ekstraksi dilakukan, rumput laut coklat (Sargassum $s p$.) dicuci dengan air tawar, kemudian direndam dengan larutan $\mathrm{KOH} \quad 0,1 \%$ sebanyak 1,5 liter selama 1 jam dan dijemur sampai kadar air berkurang $15 \%$.

Mula-mula rumput laut coklat kering direndam dalam $\mathrm{HCl} 1 \%$ selama 1 jam (rasio rumput laut $\mathrm{HCl} \mathrm{1:30} \mathrm{b/v)} \mathrm{untuk}$ dimineralisasi. Setelah itu dilakukan pencucian dengan akuades sampai $\mathrm{pH}$ netral. Kemudian ekstraksi dilakukan dengan menambahkan larutan $\mathrm{Na}_{2} \mathrm{CO}_{3} 2 \%$ sebanyak $1: 30(\mathrm{w} / \mathrm{v})$ pada suhu $60^{\circ} \mathrm{C}-70^{\circ} \mathrm{C}$ selama 2 jam. Setelah itu dilakukan penyaringan hasil ekstraksi. Untuk mengendapkan asam alginat, filtrat ditambahkan $\mathrm{HCl} 10 \%$ sampai $\mathrm{pH}$ 2,8-3,2.

Asam alginat dikonversi menjadi sodium alginat dengan melakukan titrasi dengan $\mathrm{Na}_{2} \mathrm{CO}_{3} \quad 10 \%$ sampai $\mathrm{pH} 7$ dan endapan berubah menjadi filtrat kembali (Gambar 1). Kemudian dilakukan pemucatan pigmen coklat dengan penambahan $\mathrm{NaOCl} 4 \%(1: 2 \mathrm{v} / \mathrm{v})$ selama 
30 menit. Kemudian dilakukan pemisahan sodium alginat, filtrat dituangkan sedikit demi sedikit ke dalam isopropil alkohol $(1: 2 \mathrm{v} / \mathrm{v})$ sambil diaduk dan dibiarkan selama 30 menit agar terbentuk serat sodium alginat. Tahap berikutnya pengeringan, serat alginat dikeringkan dibawah sinar matahari selama \pm 12 jam. Kemudian serat alginat ditumbuk dengan mortar dan didapat hasil akhir sodium alginat berupa bubuk (Husni et al., 2012). Kemudian sodium alginat yang terbentuk dianalisis dengan FTIR, ditentukan berat molekul dan viskositasnya dengan viskometer Oswald.

Pembuatan dan karakterisasi membran komposit kitosan-sodium alginat terfosforilasi

Pembuatan membran komposit kitosan sodium alginat menggunakan metode pada penelitian Smitha et al. (2005). Pertama, membuat larutan kitosan dan sodium alginat dengan variasi 8:0, 8:1, 8:2, dan 8:4 (b/b). Keempat variasi tersebut, massa kitosan dilarutkan masing-masing $4 \mathrm{~g}$ dan massa sodium alginat berbeda-beda sesuai perbandingan. Perbandingan 8:0 tanpa penambahan sodium alginat, perbandingan 8:1 ditambah sodium alginat $0,5 \mathrm{~g}$, perbandingan 8:2 ditambah sodium alginat $1 \mathrm{~g}$ dan perbandingan $8: 4$ ditambah sodium alginat 2 g. Sebanyak 4 g kitosan dilarutkan dalam $98 \mathrm{~mL}$ akuades dan ditambahkan asam asetat glasial sebanyak 2 $\mathrm{mL}$, sedangkan sodium alginat pada masing-masing variasi dilarutkan dalam 50 $\mathrm{mL}$ akuades. Kemudian masing-masing larutan diaduk dengan pengaduk magnet dan dipanaskan pada suhu $50-60^{\circ} \mathrm{C}$ selama 6 jam. Kemudian larutan kitosan dan larutan sodium alginat tersebut didiamkan selama semalam. Kemudian campuran kedua larutan tersebut ditambah dengan $\mathrm{HCl} 1 \%$ dan di aduk selama 3 jam pada suhu $50-60{ }^{\circ} \mathrm{C}$. Setelah itu campuran disaring, lalu didiamkan semalam agar gelembung udara menghilang. Kemudian larutan dope dicetak dalam cawan petri dan dikeringkan selama 1 hari pada suhu ruang.
Selanjutnya membran akan terbentuk lalu direndam dengan $\mathrm{NaOH} 4 \%$ agar mudah dilepaskan dari cawan petri. Setelah itu membran dicuci dengan air sampai $\mathrm{pH}$ netral dan dibilas dengan akuades. Membran diletakkan diatas mika dan ditutup dengan mika agar permukaan membran menjadi rata lalu membrane dikeringkan pada suhu ruang (Smitha et al., 2005).

Kemudian membran yang terbentuk difosforilasi dengan cara direndam dalam larutan STPP $2 \mathrm{~N}$ selama 3 jam. Membran dengan 4 variasi yang sudah terfosforilasi di uji kekuatan tarik, swelling air dan KPI (Kapasitas Penukar Ion) untuk mendapatkan membran yang optimal. Setelah mendapatkan membran yang optimal kemudian dilakukan karakterisasi dengan SEM, FTIR, uji konduktivitas proton, dan uji permeabilitas methanol.

\section{Hasil dan Pembahasan}

\section{Ekstraksi Rumput Laut Coklat}

Dari ekstraksi rumput laut coklat dihasilkan sodium alginat dengan rendemen sebesar $26,38 \%$, berat molekul $42071 \mathrm{~g} / \mathrm{mol}$ dan viskositasnya 84,14 cps. Spektra hasil FTIR sodium alginat hasil ekstraksi dan sodium alginat komersil ditunjukkan pada Gambar 1.

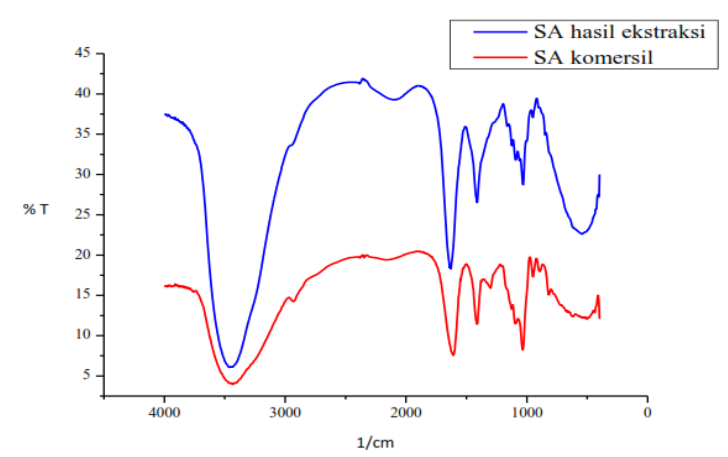

Gambar 1. Hasil spektra FTIR sodium alginat hasil ekstraksi dan komersil

Dari dua spektra tersebut terdapat kemiripan gugus fungsi. Pada gambar 4.6 menunjukkan ciri khas berupa gugus $\mathrm{OH}$ stretching di bilangan gelombang 3436,91 $\mathrm{cm}^{-1}$ pada sodium alginat komersil, sedangkan pada sodium alginat hasil 
ekstraksi muncul di bilangan gelombang $3433,06 \mathrm{~cm}^{-1}$ dan pada sodium alginat di literatur muncul pada bilangan gelombang $3457 \mathrm{~cm}^{-1}$. Gugus $\mathrm{C}=\mathrm{O}$ stretching $\mathrm{di}$ bilangan gelombang $1627,81 \mathrm{~cm}^{-1}$ pada sodium alginat komersil, sedangkan pada sodium alginat hasil ekstraksi muncul di bilangan gelombang $1608,52 \mathrm{~cm}^{-1}$ dan pada sodium alginat di literatur muncul pada bilangan gelombang $1617 \mathrm{~cm}^{-1}$. Ikatan C$\mathrm{O}-\mathrm{H}$ di bilangan gelombang $1411,80 \mathrm{~cm}^{-1}$ pada sodium alginat komersil, sedangkan pada sodium alginat hasil ekstraksi muncul di bilangan gelombang $1411,80 \mathrm{~cm}^{-1}$ dan pada sodium alginat di literatur muncul pada bilangan gelombang $1418 \mathrm{~cm}^{-1}$. Terdapat ikatan C-O-C di bilangan gelombang $1029,92 \mathrm{~cm}^{-1}$ pada sodium alginat komersil, sedangkan pada sodium alginat hasil ekstraksi muncul di bilangan gelombang $1033,77 \mathrm{~cm}^{-1}$ dan pada sodium alginat di literatur muncul pada bilangan gelombang $1030 \mathrm{~cm}^{-1}$. Hasil uji FTIR dari sodium alginat komersil dan hasil ekstraksi memiliki peak yang mirip menunjukkan bahwa gugus fungsi yang terdapat pada kedua serbuk tersebut sama. Hal ini membuktikan bahwa serbuk hasil ekstraksi merupakan sodium alginat.

Pembuatan dan Karakterisasi Membran Komposit Kitosan-Sodium Alginat Terfosforilasi

Membran ini transparan berwarna putih kekuningan. Membran yang dihasilkan dikarakterisasi gugus fungsinya dengan FTIR dan hasil spektranya menunjukkan bahwa pada membran tidak terdapat gugus fungsi baru, tetapi tetap terdapat gugus fungsi kitosan yang berupa hidroksil dan amino serta sodium alginat terdapat gugus fungsi hidroksil dan karboksilat.

Pada spektra pertama Gambar 2 terdapat gugus $\mathrm{OH}$ dan $\mathrm{N}-\mathrm{H}_{2}$ membran sebelum difosforilasi, setelah difosforilasi dan literatur berturut-turut pada bilangan gelombang $3502,49-3101,32 \mathrm{~cm}^{-1}$; $3581,93 \mathrm{~cm}^{-1}$; dan $3421 \mathrm{~cm}^{-1}$. Selain itu terdapat ikatan -COO streching asym berturut-turut pada bilangan gelombang
$1639,38 \mathrm{~cm}^{-1} ; 1649,19 \mathrm{~cm}^{-1}$; dan $1616 \mathrm{~cm}^{-}$ 1. Terdapat pula ikatan COO- stretching sym berturut-turut pada bilangan gelombang $1423,37 \mathrm{~cm}^{-1} ; 1419,66 \mathrm{~cm}^{-1}$; dan $1417 \mathrm{~cm}^{-1}$. Pada membran terfosforilasi muncul peak baru pada bilangan gelombang $1151,54 \mathrm{~cm}^{-1}$ sebagai gugus fungsi $\mathrm{P}=\mathrm{O}$ atau fosfat yang sesuai dengan penelitian Rakhmaningtyas tahun 2012. Setelah dilakukan fosforilasi terbentuk ikatan baru berupa ikatan ionic antara gugus $\mathrm{NH}^{3+}$ dari kitosan dengan gugus tripolifosfat (Wan et al., 2003).

Dari kedua spektra pada Gambar 2 terdapat perbedaan antara sebelum dan setelah difosforilasi. Perbedaan spektra ini menunjukkan bahwa proses fosforilasi berlangsung baik dan terbentuk ikatan baru. Ikatan baru dari gugus amonia pada kitosan dengan tripolifosfat memunculkan peak baru pada spektra.

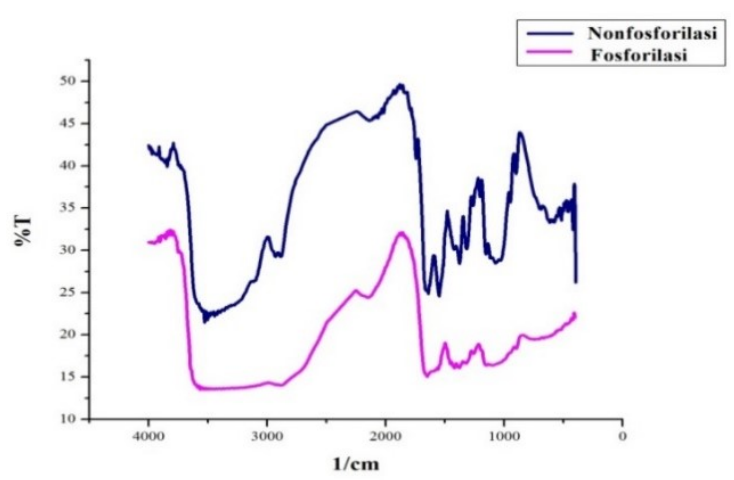

Gambar 2. Hasil spektra FTIR membran komposit nonfosforilasi dan fosforilasi

Penentuan Membran yang Mempunyai Sifat Mekanik Optimal

Untuk menentukan variasi membran yang optimal dilakukan uji sifat mekanik, uji swelling air dan uji KPI. Nilai Modulus Young membran 4 variasi ditunjukkan pada Gambar 3. Membran yang memiliki nilai Modulus Young terbesar adalah variasi 8:1 (b/b). 


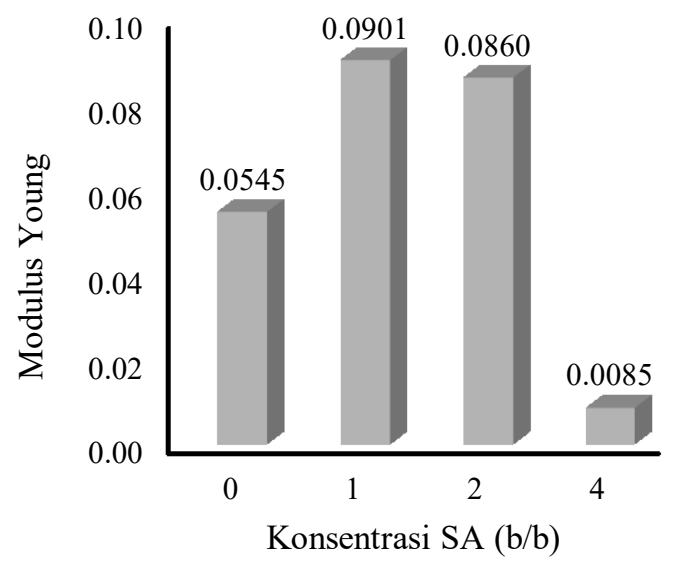

Gambar 3. Diagram antara variasi komposisi membran dengan nilai Modulus Young

Hasil uji swelling air ditunjukkan pada Gambar 4. Membran yang memiliki swelling air terkecil adalah variasi 8:1. Sedangkan hasil uji KPI ditunjukkan pada Gambar 5. Membran yang memiliki KPI terbesar adalah variasi 8:2. Dalam hal ini yang dipilih sebagai membran optimal adalah yang memiliki sifat mekanik yang kuat karena agar membran tidak rapuh, tetapi juga memiliki kinerja yang baik sebagai PEM, yakni memiliki swelling air yang kecil dan KPI yang relatif besar. Jadi membran yang optimal pada penelitian ini adalah variasi $8: 1(\mathrm{~b} / \mathrm{b})$.

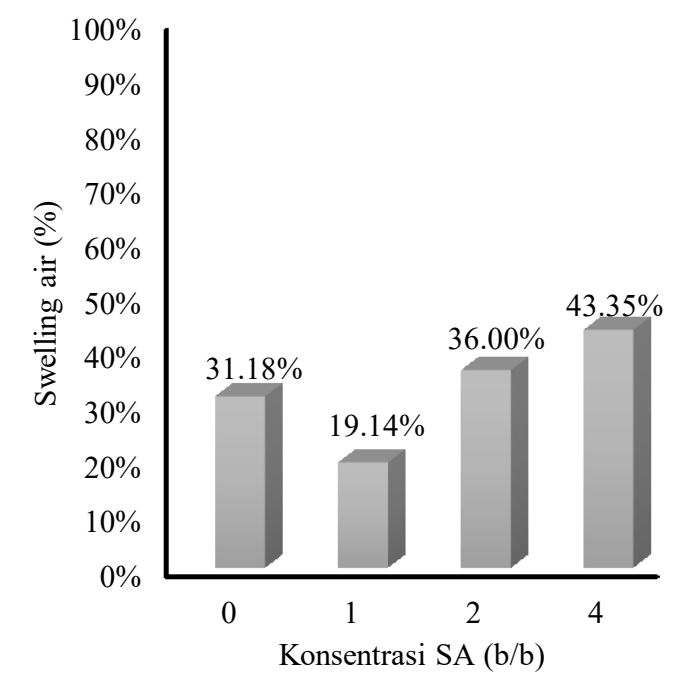

Gambar 4. Diagram antara variasi komposisi membran dengan swelling air

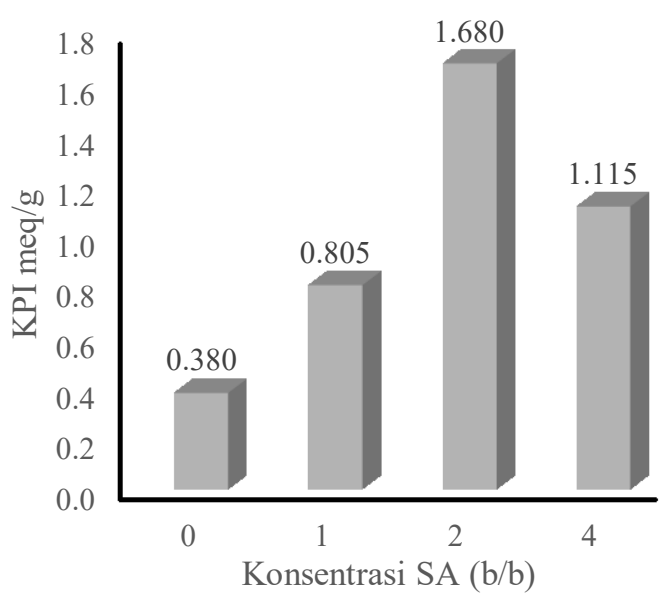

Gambar 5. Diagram antara variasi komposisi membran dengan KPI

Pada fuel cell dibutuhkan membran yang memiliki swelling air yang kecil karena jika swelling air besar maka PEM akan mudah menggembung, sehingga dapat memperbesar pori-pori dan dapat menurunkan kinerja PEM sebagai pemisah antara anoda dengan katoda (Dhuhita dan Arti, 2010). Sedangkan KPI pada membran komposit kitosan-sodium alginat terfosforilasi hasil dari penelitian ini lebih besar daripada Nafion 117 yaitu 0,91 $\mathrm{m}_{\text {eq }} / \mathrm{g}$. Pada PEM dibutuhkan KPI yang besar, karena semakin besar KPI maka kemampuan membran untuk meneruskan proton dari anoda ke katoda juga semakin baik (Smitha et al., 2005).

\section{Hasil uji morfologi menggunakan SEM}

Dari hasil uji SEM terlihat morfologi membran (a) terlihat pori-pori yang tersebar dengan ukuran pori $2-3,7 \mu \mathrm{m}$. Jika dibandingkan struktur membran (a) dan lebih rapat dan terlihat rata dibandingkan dengan membran (b).

\section{Hasil uji konduktivitas proton}

Uji penentuan konduktivitas proton dilakukan untuk mengetahui estimasi konduktivitas $\mathrm{H}^{+}$yang merupakan fungsi utama dari membran pertukaran proton. Konduktivitas proton ditentukan menggunakan EIS (Electrochemical Impedance Spectroscopy) tetapi 
sebelumnya direndam dengan $\mathrm{H}_{2} \mathrm{SO}_{4} 0,2 \mathrm{M}$ terlebih dahulu untuk mengaktifkan permukaan membran.

Konduktivitas proton yang didapatkan sebesar 4,7 x $10^{-5} \mathrm{~S} / \mathrm{cm}$. Hasil konduktivitas proton ini jika dibandingkan dengan konduktivitas proton Nafion 117 sebesar $0,086 \mathrm{~S} / \mathrm{cm}$ maka hasil konduktivitas proton membran komposit kitosan-sodium alginat masih sangat kecil. Penambahan sodium alginat dan fosforilasi setidaknya dapat meningkatkan nilai konduktivitas proton dan lebih tinggi jika dibandingkan dengan nilai konduktivitas proton kitosan yaitu sebesar $3,16 \times 10^{-7} \mathrm{~S} / \mathrm{cm}$ (Sudaryanto et al., 2012). Konduktivitas proton pada PEM harus memiliki nilai yang tinggi agar proses perpindahan proton dari anoda ke katoda berjalan maksimal.
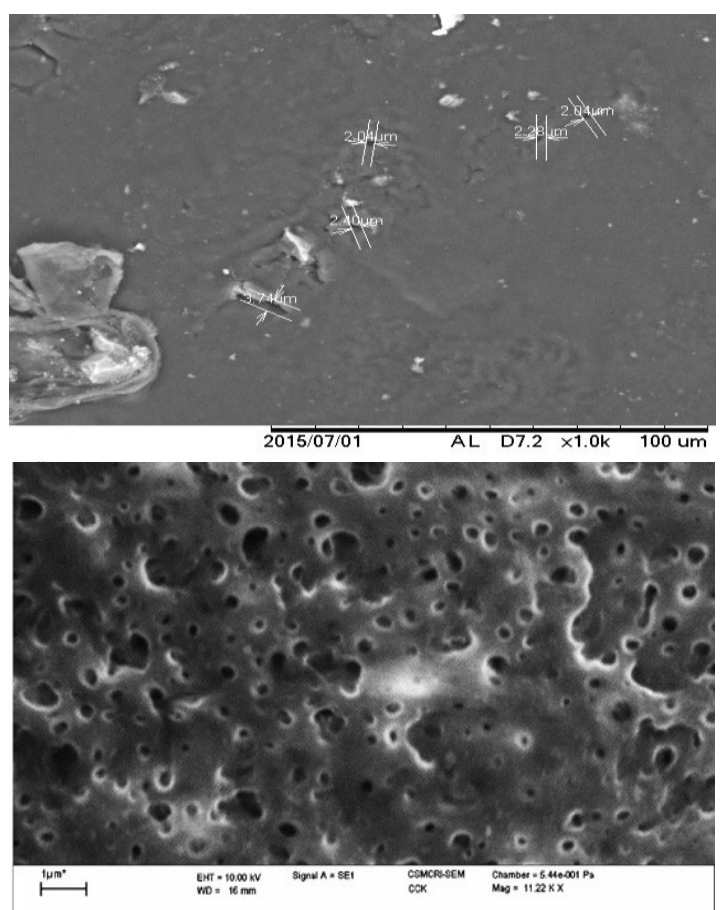

Gambar 6. Hasil uji morfologi dengan SEM. (a) Permukaan atas membran dan (b) Penampang melintang membran

\section{Hasil uji permeabilitas metanol}

Uji permeabilitas metanol bertujuan untuk mengetahui ketahanan membran terhadap metanol. Uji ini dilakukan menggunakan alat difusi dengan $5 \mathrm{M}$ metanol pada membran. Volume metanol yang keluar dicatat. Permeabilitas metanol yang diperoleh sebesar $72,7 \times 10^{-7} \mathrm{~kg} / \mathrm{cm}^{2} \mathrm{~s}$. Hasil ini mendekati nilai permeabilitas metanol Nafion 117 pada penelitian Smitha et al. tahun 2005 yaitu sebesar $27,6 \times 10^{-8}$ $\mathrm{kg} / \mathrm{cm}^{2} \mathrm{~s}$. Pada PEM nilai permeabilitas metanol harus memiliki nilai kecil agar metanol tidak menembus membran dan keluar dari area anoda sehingga metanol sebagai bahan bakar pada fuel cell semakin banyak terbuang. Membran hasil penelitian ini memiliki kemampuan yang cukup baik untuk bisa diaplikasikan sebagai PEM pada fuel cell karena nilai permeabilitas metanol mendekati nilai permeabilitas metanol Nafion 117.

\section{Kesimpulan}

PEM dapat dibuat dari bahan polimer alam, yaitu kitosan dan sodium alginat. Jika kedua larutan tersebut dicampurkan maka akan terbentuk larutan dope yang dapat dicetak untuk menjadi membran komposit kitosan-sodium alginat yang kemudian difosforilasi dengan STPP 2N.Variasi perbandingan komposisi kitosan dan sodium alginat yang optimal adalah dengan perbandingan $8: 1(\mathrm{~b} / \mathrm{b})$ yang memiliki Modulus Young sebesar $0,0901 \mathrm{kN} / \mathrm{cm}^{2}$ dan swelling air sebesar 19,14\%. Membran komposit-kitosan terfosforilasi yang optimal memiliki konduktivitas proton sebesar $4,7 \times 10^{-5} \mathrm{~S} / \mathrm{cm}$, permeabilitas metanol sebesar $72,7 \times 10^{-7}$.

\section{Daftar Pustaka}

Husni, A., Subaryono, Pranoto, Y. dan Tazwir, U. (2012). Pengembangan Metode Ekstraksi Alginat dari Rumput Laut Sargassum sp. sebagai Bahan Pengental, Agritech, 32, $1-8$

Kim, Y. S., Kim, D. S., Guiver, M. D. and Pivovar, B. S. (2011). Interpretation of Direct Methanol Fuel Cell Electrolyte Properties Using Non-Traditional Length-Scale Parameters, Journal of Membrane Science, 374, 49-58 
Moura, M.R., Aouada F. A., AvenaBustillos R. J., McHugh T. H., Krochta J. M. and Mattoso L. H. C. (2008). Improved Barrier and Mechanical Properties of Novel Hydroxypropylmethylcellulose Edible Films with Chitosan/Tripolyphosphate Nanoparticles, Journal of Food Engineering, 92, 448 - 453

Raharjo, J., Dedikarni, Wan, D. dan Wan, R. (2007). Perkembangan Teknologi Material pada Sel Bahan Bakar Padat Suhu Operasi Menengah, Indonesian Journal of Material Science, 10, 28-34

Smitha, B., Sridhar, S. and Khan, A.A. (2005). Chitosan-Sodium Alginate Polyion Complexes as Fuel Cell Membranes, European Polymer Journal, 41, 1859 - 1866

Smitha, B., Devi, A.D. and Sridhar, S. (2008). Proton-Conducting Composite Membrane of Chitosan and Sulfonated Polysulfone for Fuel Cell Application, International Journal of Hydrogen Energy, 33, 4138 - 4146

Sudaryanto, Yulianti E., Dimyati A. dan Jodi H. (2012). Pengembangan Elektrolit Padat Berbasis Kitosan untuk Baterai Kendaraan Listrik, Pusat Teknologi Bahan Industri Nuklir, BATAN, 84, 1 - 10

Yohan, N., R. M., Hendrajaya, L. dan Siradj, E. S. (2005). Sintesis Bahan Membran Sel Bahan Bakar Kopolimerisasi Stirena pada Film ETFE dengan Teknik Iradiasi Awal, Teknologi, 9, $72-77$

Williams, M. C. (2011). Fuel Cells: Technologies for Fuel Processing, Elsevier, Spain.

Wan, Y., A.M. Katherine, Creber, Peppley, B. and Tam Bui, V. (2003), Synthesis, Characterization and Ionic Conductive Properties of Phosphorylated Chitosan Membranes, Macromol Chemistry Physic, 204, 850 - 858
Wang, Y., Yang, D., Zheng, X., Jiang, Z. and Li, J. (2008). Zeolite Beta-Filled Chitosan Membrane with Low Methanol Permeability for Direct Methanol Fuel Cell, Journal of Power Sources, 183, $454-463$.

Wee, J. (2006). Applications of Proton Exchange Membrane Fuel Cell Systems, Renewable and Sustainable Energy Reviews, 11, 1720 - 1738. 